\title{
EFFECT OF ORIGANUM VULGARE AS A FEED ADDITIVE ON GROWTH PERFORMANCE, FEED UTILIZATION AND WHOLE BODY COMPOSITION OF NILE TILAPIA (Oreochromis niloticus) FINGERLINGES CHALLENGED WITH PATHOGENIC Aeromonas hydrophila.
}

Seden, M. E. A. ${ }^{1}$; Fayza E. Abbass ${ }^{2}$ and M. H. Ahmad ${ }^{1}$

1- Department of Fish Nutrition and ${ }^{2}$ Department of Fish Production and Aquaculture Systems,

2- Central Laboratory for Aquaculture Research, Abbassa, AboHammad, Sharqia, Egypt.

\begin{abstract}
The effect of dietary inclusion popelevels of Origanum vulgare as a feed additive compared with a control diet for 13 weeks on growth performance, feed utilization, whole body composition, entropathogenic Aeromonas hydrophila-challenge and economic efficiency for production of one $\mathrm{Kg}$ gain of Nile tilapia Oreochromi niloticus were studied. All experimental diets were iso-nitrogenous (30\% crude protein) and iso-caloric (4.42 k cal $/ g$ diet) with or without Origanum vulgare addition. Fifteen glass aquaria were used, each one was stoked with 15 fish $(1.88 \pm 0.01 \mathrm{~g} / \mathrm{fish})$ and three aquaria were designated for each treatment. The five treatments were: treatment 1 (was a control diet without additives), and four treatments (T2,T3,T4,T5) contained $0.5 \%, 1.0 \%, 1.5 \%$ and $2.0 \%$ of Origanum vulgare respectively . Fish were fed on one of these experimental diets at feeding level of $8 \%$ of fish body weight for the first four weeks then reduced to $5 \%$ for the next four weeks and then reduced to $3 \%$ for the remaining period of the experimental .The feed offered twice daily for six days per week. The results of this study revealed that, fish growth indicated as final weight, weight gain, daily gain, relative growth rate (RGR), and specific growth rate (SGR)\} was increased gradually and the maximum growth was obtained when fish fed the diet contained $1 \%$ of Origanum vulganwhile the lowest growth was obtained from the control group. The highest feed intake and the best feed conversion ratio (FCR) were obtained when fish fed at $1 \%$ of Origanum vulgar. The lowest feed conversion ratio (FCR) was obtained of the control diet, and the highest feed efficiency ratio (FER),protein efficiency ratio (PER), apparent protein utilization (APU), and energy utilization (EU) were enhanced significantly when fish fed diet contained $1 \%$ of Origanum vulgare compered with control diet. Moreover, Dry matter (DM) and crude protein (CP)were similarly at all the experimental groups, but, the highest crude fat (CF)was obtained from the diet contained $0.5 \%$ of Origanum vulgar( T3) and the lowest (CF) was obtained from fish fed diet contained $1 \%$ of Origanum vulgare (T4). The highest reduction in feed cost compared with control diet showed to produce one $\mathrm{kg}$ fish gain of treatment containing $1 \%$ Origanum. The results of fish challenge against $A$. hydrophila for 10 days, mortality percentage did not observe in fish fed with diet containing different levels of Origanum, while mortality percentage in fish of control group was $90 \%$. This study clearly showed that the optimum level of Origanum vulgarein a practical Nile tilapia diet is $1 \%$.

Keywords: Medical plants, Origanum vulgar, Nile tilapia, growth performance, feed utilization, whole body composition, Aeromonas hydrophila and
\end{abstract} economic evaluation. 


\section{INTRODUCTION}

Medicinal plants as natural growth promoters have significant improvements on body weight, weight gain, survival rate and feed conversion rate in broilers (Ibrahim et al., 1998 and Tollba 2003) and in fish (Shalaby, 2004 and El Dakar, 2004).The use of medicinal herbs and plants for humans has been well known since the old civilizations of ancient Egyptians. Several medicinal herbs are used in the medication of various diseases, for example help to reduce high blood cholesterol concentration, providing some production against cancer, protect against chronic diseases and / or stimulate the immune system .Furthermore, these herbs are not only serve as a medicinal purpose but also contain aromatic substances and essential oils used in food industries (Evans and Pharm, 1975 and Craig, 1999). The essential oils from extracted aromatic plants have been shown antibacterial (Dorman and Deans,2000; Mitsch et al.,2004), anticoccidial (Giannenas et al. 2003; Jamroz et al., 2003), antifungal (Jantan et al., 2003 and antioxidant activities Bamsaciuglu, 2004; Botsoglou et al., 2004). The most recent studies showed successful use of spices and natural herbs in fish nutrition including marjhoram, baisl, licorice roots, black seeds, peppermint leaves, fenugreek seeds and caraway seeds (Abd El-Maksoud et al., 2002; Abd- Elmonem et al., 2002 ; Sakr,2003; Shalaby et al., 2003; ElDakar et al., 2004 ; Shalaby ,2004 and El-Dakar ,2004.The genus origanum Bth. of the Labiatae is represented in the Egyptian wild flora by fruticose shrubs or perennial herbs with ovate, entire leaves. The inflorescnces are corymbose or paniculateds. In the "Manual of Egypt" (Montasir and Hassib, 1956), this genus can be differentiated into two species. O.vulgare Linn and O.Maru Linn V.sinaicum Boiss .Origanum vulgare is a native to the Mediterranean, Euro-Siberian and Irano-Siberian regions (Aligiannis, et al., 2001). Due to the variability in chemical and aromatic characteristics, Origanum plants belonging to different species and ecotypes are widely used in agriculture, pharmaceutical and cosmetic industries as a culinary herb, flavoring substance of food products,alcoholic beverages and perfumery for their spicy fragrance. The content of essential oils and extracts of Origanum species have antimicrobial, antioxidant and other biological activities,which may change according to the differences in cultivation, origin, vegetative stage and growing seasons of the plants (Aligiannis et al., 2001 and Milos et al., 2000).

Tilapia Farming has grown extremely fast in the last decade, where they are cultured worldwide with annual growth rate of about $12.2 \%$ (EISayed,2006).Tilapia are widely distributed in many countries of the world. In Egypt, Nile tilapia is a major species in aquaculture system and much appreciated by consumers. However, the success of intensive tilapia culture depends to a large extent on supplemental feeding. The objectives of the present study were to evaluate the effect of Origonum vulgare as a feed additive at different levels $(0.5,1.0,1.5$ and $2.0 \%)$ in diets for Nile tilapia, Oreochromis niloticus (L.)on growth performance, feed utilization, wholebody composition, $A$. hydro phyla challenge and economical evaluation. 


\section{MATERIALS AND METHODS}

\section{Fish and culture technique:}

The present study was carried out in the nutritional laboratory at the Central Laboratory of Aquaculture Research, Abbassa, Abo-Hammad, Sharkia, Egypt. Five experimental diets were formulated and containing (30.36\%crude protein, $7.31 \%$ crud fat and $4.42 \mathrm{k} \mathrm{cal} / \mathrm{g}$ diet).These diets contained different levels of Origanum vulgare, control 0.0, 0.5, 1.0, 1.5 and $2 \%$ of diet respectively. Dietary formulation and proximate composition of the experimental diets are shown in Table (1) and Table (2) respectively. In the present study; all the ingredients of the experimental diets were obtained from the local market( Z00-control factory), while Origanum vulgare (natural product) had been obtained from local market. The dry ingredients of each diet were thoroughly mixed and then $100 \mathrm{~mL}$ of water per $\mathrm{kg}$ diet was supplemented and the ingredients were blended using kitchen blender to make a paste of diet to pelleting with $\mathrm{a}(1 \mathrm{~mm})$ diameter matrix. The pellets were dried in a drying oven model (Fisher oven $13-261-28 \mathrm{~A}$ ) for 24 hours on $85^{\circ} \mathrm{C}$ and stored in plastic bags and finally kept in a refrigerator at $2^{\circ} \mathrm{C}$ during the experimental period to avoid rancidity. Experimental diets were formulated to meet the requirements of fish according to NRC,(1994)

\section{Fish rearing:}

Fry of Nile tilapia, Oreochromis niloticus (L) with an average initial body weight of $1.88 \mathrm{~g} /$ fish were obtained from the fish hatchery ponds, Central Laboratory for Aquaculture research, Abu-Hammad, Sharkia, Egypt, and kept for 2 weeks as an acclimation period to the laboratory conditions. After that, fish were distributed in fifteen glass aquaria; $100 \mathrm{~L}$ for each treatment was represented by three aquaria. Each aquarium was supplied with compressed Air via air- stones using aquarium air pumps. Fish were acclimatized one week to the aquarium condition and fish feces were cleaned daily by siphoning with a one of the three quarters of aquariums water and was replaced by aerated tape water from a storage tank for 24 hours All aquaria were maintained at $26-28^{\circ} \mathrm{C}$ with $12-12$ light- dark photoperiod cycle using fluorescent tubes as the light source. The daily feeding rate was $8 \%$ of live body weight for the first four weeks then reduced to $5 \%$ for the next four weeks and further reduced to $3 \%$ for the remaining period of the experiment. The feed was offered twice daily; 6 days a week for 13 weeks.Fish were weighted every two weeks and the mount of feed quantity for each aquarium was adjusted.

\section{Chemical analysis of diets and fish body.}

The tested diets and whole-fish body from each treatment at the beginning and at the end of experiment were analyzed according to the methods of AOAC (1990) for the moisture, protein, fat and ash. Meanwhile, Crude fiber was estimated according to Goering and Van Soest (1970). Gross energy was calculated according to NRC (1993). 


\section{Physico-chemical parameters of water:}

Water samples were collected biweekly from each aquarium. Water temperature and dissolved oxygen were measured on site with a YSI model 58 oxygen meter (Yellow Spring Instrument Co., Yellow Spring, Ohio, USA). While the $\mathrm{pH}$ degree was measured using a $\mathrm{pH}$-meter (Digital Mini-pH Meter, model 55, Fisher Scientific, USA). Unionized ammonia was measured using DREL/2 HACH kits (HACH Co., Loveland, Colorado, USA), Boyd (1990).

\section{Growth parameters:}

Weight gain $(W G)=W 2-W 1$

Daily gain $(D G)=W 2-W 1 / T$

Relative growth rate $(R G R)=[(W 2-W 1) / W 1] \times 100$;

Where $\mathrm{W} 2$ = average final body weight $(\mathrm{g}), \mathrm{W} 1$ = average initial body weight $(\mathrm{g})$, and $\mathrm{T}=$ experimental period (days).

\section{Feed utilization parameters:}

Feed conversion ratio $(\mathrm{FCR})=$ feed intake $(\mathrm{g}) /$ body weight gain $(\mathrm{g})$;

Feed efficiency ratio (FER) = body weigh gain $(\mathrm{g}) /$ feed intake $(\mathrm{g}) \times 100$;

Protein efficiency ratio $(P E R)=$ gain in weight $(g) /$ protein intake in feed $(g)$; Apparent protein utilization (APU \%) $=100$ [protein gain in fish $(\mathrm{g}) /$ protein intake in feed $(\mathrm{g})$ ].

Energy utilization $(E U \%)=$ [energy gain in fish / energy intake in feed] $\times 100$.

\section{Challenge test:}

After 90 days of feeding on experimental diets, fish of each group were divided into two subgroups; the first subgroup was challenged I/P with pathogenic Aeromonas hydrophila $\left(0.3 \mathrm{ml}\right.$ of $\left.5 \times 10^{5} \mathrm{CFU}\right)$, Schäperclaus et al., (1992), which obtained from Fish Disease Department, Central Laboratory for Aquaculture Research, Abbassa, Abo-Hammad, Sharqia, Egypt. The second subgroup was injected I/P with $0.3 \mathrm{ml}$ of saline solution as a control. Both subgroups were kept under observation for 10 days whereas incidences of daily mortality were recorded.

\section{Economical evaluation:}

The cost of feed required to produce a unit of fish biomass was estimated using a simple economic analysis. The estimation was based on the local retail sale market price of all the dietary ingredients during the time of this study. These prices (in LE/ $/ \mathrm{kg}$ ) were as follows: herring fish meal, 12; soybean meal, 2.0; corn meal, 1.50; starch 3.0, cellulose 3.0; fish oil, 7.0; corn oil, 5.0; vitamin premix, 7.0; mineral mixture, 3.0; Origanum, 30.

\section{Statistical analysis:}

All numerical data obtained in the present study were analysized to one way ANOVA. Differences between means were tested at the $5 \%$ probability level using Duncan test. All the statistical analyses were done using SPSS program version 10 (SPSS, Richmond, VI, USA) as described by Dytham (1999). 


\section{RESULTS AND DISCUSSION}

The values of water quality parameters showed that temperature range was $27-29 \mathrm{C}$, dissolved oxygen range was $5.3-5.8 \mathrm{mg} / \mathrm{L}$, $\mathrm{pH}$ range $7.5-$ 8 and total ammonia (NO3 mg / L) range was $0.7-0.9$. These data were within the acceptable ranges required for normal growth of tilapia as mentioned by Boyd (1990).

The experimental diets contained $30 \%$ crude protein and $4.4 \mathrm{kcal} / \mathrm{g}$ diet .Table $(1,2)$ are similar to that used by (Abdel -Wahab et al., 2007). Inital body weight at all experimented groups did not differ significantly. Table( 3 ). Nile tilapia fed on treated diets actively and efficiently grew without any external signs of nutritional deficiency.Therefor growth performance (final weight, weight gain, daily gain, RGR and SGR) increased significantly $(P<0.05)$ with supplemented diets with different levels of extracted Origanum vulgare for Nile tilapia diet compered with control diet. Table (3). The highest growth was obtained at $1 \%$ Origanum vulgare diet, whereas the control diet gave the lowest fish growth performance. No significant differences in fish survival rate among different treatments $(P>0.05)$, and its range was $95 \%-$ $99 \%$. These results might be due to supplemented diets with extracted Origanum vulgare which enhance fish growth, feed utilization and immunity. Nowadays, there is an incrase for using these herbs as natural growth promoters via improving the general health by( Abd elhamid et al .,2002,2004 and 2005; Abd-Elmonem et al., 2002; Shalaby et al ., 2003 and El-Dakar et al .,2004)

Table 1: Composition experimental diets (on DM-basis) of.

\begin{tabular}{|c|c|c|c|c|c|}
\hline \multirow{3}{*}{ Items\% } & \multirow[t]{2}{*}{ Control } & \multicolumn{4}{|c|}{$\begin{array}{c}\text { Origanum vulgare levels in experimental } \\
\text { rations }\end{array}$} \\
\hline & & $0.5 \%$ & $1.0 \%$ & $1.5 \%$ & $2.0 \%$ \\
\hline & T1 & T2 & T3 & T4 & T5 \\
\hline Herring fish meal & 15.00 & 15.00 & 15.00 & 15.00 & 15.00 \\
\hline Soybean meal & 40.00 & 40.00 & 40.00 & 40.00 & 40.00 \\
\hline Corn flour & 30.00 & 30.00 & 30.00 & 30.00 & 30.00 \\
\hline Starch & 6.50 & 6.00 & 5.50 & 5.00 & 4.50 \\
\hline Cellulose & 3.00 & 3.00 & 3.00 & 3.00 & 3.00 \\
\hline Corn oil & 1.00 & 1.00 & 1.00 & 1.00 & 1.00 \\
\hline Fish oil & 1.50 & 1.50 & 1.50 & 1.50 & 1.50 \\
\hline Vitamins premix $^{1}$ & 1.00 & 1.00 & 1.00 & 1.00 & 1.00 \\
\hline Minerals premix ${ }^{2}$ & 2.00 & 2.00 & 2.00 & 2.00 & 2.00 \\
\hline Origanum vulgare & 0.00 & 0.50 & 1.00 & 1.50 & 2.00 \\
\hline Total & 100 & 100 & 100 & 100 & 100 \\
\hline
\end{tabular}

1- Vitamins premix (per $\mathrm{kg}$ of premix): thiamine, $2.5 \mathrm{~g}$; riboflavin, $2.5 \mathrm{~g}$; pyridoxine, $2.0 \mathrm{~g}$ inositol, $100.0 \mathrm{mg}$; biotin, $0.3 \mathrm{~g}$; pantothenic acid, $100.0 \mathrm{~g}$; folic acid, $0.75 \mathrm{~g}$; paraaminobenzoic acid, $2.5 \mathrm{~g}$; choline, $200.0 \mathrm{~g}$; nicotinic acid, $10.0 \mathrm{~g}$; cyanocobalamine, 0.005 g; a-tocopherol acetate, $20.1 \mathrm{~g}$; menadione, $2.0 \mathrm{~g}$; retinol palmitate, 100,000 IU; cholecalciferol, 500,000 IU.

2- Minerals premix (g/kg of premix): $\mathrm{CaHPO}_{4} .2 \mathrm{H}_{2} \mathrm{O}, 727.2 ; \mathrm{MgCO}_{4} .7 \mathrm{H}_{2} \mathrm{O}, 127.5 ; \mathrm{KCl} 50.0$; $\mathrm{NaCl}, 60.0 ; \mathrm{FeC}_{6} \mathrm{H}_{5} \mathrm{O}_{7} .3 \mathrm{H}_{2} \mathrm{O}, 25.0 ; \mathrm{ZnCO}_{3}, 5.5 ; \mathrm{MnCl}_{2} .4 \mathrm{H}_{2} \mathrm{O}, 2.5 ; \mathrm{Cu}(\mathrm{OAc})_{2} . \mathrm{H}_{2} \mathrm{O}, 0.785$; $\mathrm{COCl}_{3 .} .6 \mathrm{H}_{2} \mathrm{O}, 0.477 ; \mathrm{CaIO}_{3} .6 \mathrm{H}_{2} \mathrm{O}, 0.295 ; \mathrm{CrCl}_{3} .6 \mathrm{H}_{2} \mathrm{O}, 0.128 ; \mathrm{AlCl}_{3} .6 \mathrm{H}_{2} \mathrm{O}, 0.54 ; \mathrm{Na}_{2} \mathrm{SeO}_{3}$, 0.03 . 
Seden, M. E. A. et al.

Table 2: The chemical composition of experimental diets (on DM-basis).

\begin{tabular}{|c|c|c|c|c|c|}
\hline \multirow[b]{2}{*}{ Items } & \multirow[t]{2}{*}{ Control } & \multicolumn{4}{|c|}{ Origanum vulgare levels in experimental rations } \\
\hline & & $0.5 \%$ & $1.0 \%$ & $1.5 \%$ & $2.0 \%$ \\
\hline Dry matter & 91.80 & 91.79 & 91.81 & 91.83 & 91.82 \\
\hline Crude protein & 30.36 & 30.37 & 30.35 & 30.36 & 30.38 \\
\hline Total lipids & 7.31 & 7.33 & 7.32 & 7.30 & 7.29 \\
\hline Crude fiber & 5.84 & 5.85 & 5.86 & 5.88 & 5.88 \\
\hline Ash & 7.07 & 7.10 & 7.08 & 7.11 & 7.09 \\
\hline NFE $^{1}$ & 49.42 & 49.35 & 49.39 & 49.35 & 49.36 \\
\hline GE (Kcal/kg diet) ${ }^{2}$ & 4441.10 & 4416.10 & 4415.60 & 4412.70 & 4413.30 \\
\hline P/E ratio (mg / kcal) & 68.36 & 68.77 & 68.73 & 68.80 & 68.84 \\
\hline
\end{tabular}

1- Nitrogen-Free Extract (calculated by difference $)=100-($ protein + lipid + ash + crude fiber).

2- Gross energy (GE): Calculated from (NRC, 1993 ) as 5.65, 9.45 and $4.1 \mathrm{Kcal} / \mathrm{g}$ for protein, lipid and NFE, respectively.

Table 3: Growth performance (means \pm SE) of Nile tilapia fed five experimental diets containing different level of Origanum vulgare

\begin{tabular}{|l|c|c|c|c|c|}
\hline \multirow{2}{*}{ Items } & \multicolumn{6}{|c|}{ Origanum vulgare levels in experimental rations } \\
\cline { 2 - 6 } & Control & $\mathbf{0 . 5 \%}$ & $\mathbf{1 . 0 \%}$ & $\mathbf{1 . 5 \%}$ & $\mathbf{2 . 0 \%}$ \\
\hline & $1.88^{\mathrm{a}}$ & $1.88^{\mathrm{a}}$ & $1.87^{\mathrm{a}}$ & $1.87^{\mathrm{a}}$ & $18.7^{\mathrm{a}}$ \\
Initial weight (g) & \pm 0.00 & \pm 0.00 & \pm 0.01 & \pm 0.01 & \pm 0.03 \\
\hline & $13.25^{\mathrm{e}}$ & $16.56^{\mathrm{d}}$ & $20.70^{\mathrm{de}}$ & $17.84^{\mathrm{bc}}$ & \\
Final weight (g) & \pm 0.52 & \pm 0.72 & \pm 1.07 & \pm 0.02 & $16.47^{\mathrm{d}} \pm 0.68$ \\
\hline & $11.37^{\dagger}$ & $14.68^{\mathrm{e}}$ & $18.88^{\mathrm{ab}}$ & $16.00^{\mathrm{cde}}$ & $15.00^{\mathrm{de}}$ \\
Weight gain (g) & \pm 0.52 & \pm 0.71 & \pm 1.06 & \pm 0.03 & \pm 0.72 \\
\hline & $0.13^{\mathrm{e}}$ & $0.16^{\mathrm{d}}$ & $0.21^{\mathrm{a}}$ & & $0.17^{\mathrm{c} d}$ \\
Gain rate (g/day) & \pm 0.06 & \pm 0.09 & \pm 0.01 & $0.18^{\mathrm{bcd}} \pm 0.00$ & \pm 0.09 \\
\hline & $2.17^{\mathrm{d}}$ & $2.26^{\mathrm{d}}$ & $2.66^{\mathrm{ab}}$ & $2.50^{\mathrm{bc}}$ & $2.44^{\mathrm{bc}}$ \\
SGR (\%/d) & \pm 0.04 & \pm 0.12 & \pm 0.05 & \pm 0.09 & \pm 0.07 \\
\hline & $604.79^{\mathrm{e}}$ & $779.18^{\mathrm{d}}$ & $900.10^{\mathrm{cd}}$ & $852.41^{\mathrm{cd}}$ & $804.36^{\mathrm{d}}$ \\
RGR (\%) & \pm 2.76 & \pm 3.67 & \pm 6.42 & \pm 7.34 & \pm 5.49 \\
\hline & $95.0^{\mathrm{a}}$ & $99.3^{\mathrm{a}}$ & $97.0^{\mathrm{a}}$ & $98.0^{\mathrm{a}}$ & $98.0^{\mathrm{a}}$ \\
Survival rate (\%) & \pm 0.1 & \pm 0.3 & \pm 0.1 & \pm 0.4 & \pm 0.5 \\
\hline
\end{tabular}

Means with different superscripts in the same row are significantly different $\quad(P<0.05)$.

The present results agree with those found by Shalaby (2004) who reported that feeding fenugreek seed meal to Nile tilapia improved growth rate, survival, feed utilization and immunity. The improvement of live body weight, body weight gain, weight gain \%, SGR and survival rate may be due to the presence of essential oil and extracts of Origanum species which are containing antimicrobial, antioxidant and other biological activities (Aligiannis et al., 2001 and Milos, et al., 2000). Also, these results agree with those reported by Abd El-Maksoud et al (1999) regarding Nile tilapia fingerlings (10.3 g/fish) when fed a basal diet containing $0,1,2$. and $3 \%$ marjoram leaves at a feeding rate of $3 \%$ of their body weight for 90 days. Several studies in animal nutrition showed that adding some spices or medicinal herbs to diets had favorable effects on live weight gain, feed efficiency and 
nutrient digestibility (Hanafy, 1995; Abdelhamid et al., 2004 and Abdelhamid, 2008.

Feed intake increased significantly $(P<0.05)$, while $F C R$ improved significantly by supplemented diets with different levels of Origanum vulgare Table (4). Moreover, FER, PER, APU and EU values increased significantly $(P<0.05)$ with supplements diets by Origanum vulgare level until $(1 \%)$. The best FCR and higher values of FI, FER, PER, APU, and EU were obtained when fish fed diet contained $1 \%$ Origanum vulgare level. Increased feed intake was the result of a high demand for nutrients with stimulated growth or due to improved appetite because of sensory stimulation. Similarly, El-Saidy (1999) reported that feed consumption was higher in the onion-fed Nile tilapia throughout the experimental period and the control group exhibited the lowest feed intake.El-Dakar et al .(2004) studied, the effect of dried marjoram leaves ( $0,0.5,1.0$ \& $2.0 \%$ of the diet )on Oreochromis niloticu x Oreochromis auraus fingerling averaging $13 \mathrm{~g} /$ fish for inetial weight the best of growth performance was obtained at the $2 \%$ level . The essential oil shows antioxidant (Dhuley, 1999), antibacterial (Nevas et al.,2004) antifungal (Chami et al.,2004;Wang et al .,2005)and some other therapeutic ctivities. Therefore, the use of natural feed additives is important to minimize these adverse differences in the reported antimicrobial activity of oils from the same plant.The herbs, utilized on many food products, have been shown to be rich in rosmarinic acid (Zheng and Wang, 2001).

Table 4: Means of feed intake, feed conversion ratio (FCR), protein efficiency ratio (PER), Apparent protein utilization (APU)) and energy utilization (EU) of Nile tilapia fed experimental experimental diets.

\begin{tabular}{|l|c|c|c|c|c|}
\hline \multirow{2}{*}{ Items } & Control & \multicolumn{5}{|c|}{ Origanum vulgare levels in experimental rations } \\
\cline { 3 - 6 } & & $\mathbf{0 . 5 \%}$ & $\mathbf{1} \%$ & $\mathbf{1 . 5 \%}$ & $\mathbf{2 . 0 \%}$ \\
\hline Feed intake(g) & $22.45^{\mathrm{bc}}$ & $22.53^{\mathrm{bc}}$ & $24.41^{\mathrm{a}}$ & $22.19^{\mathrm{c}}$ & $23.55^{\mathrm{ab}}$ \\
& \pm 0.31 & \pm 0.60 & \pm 0.81 & \pm 0.51 & \pm 1.02 \\
\hline FCR & $1.99^{\mathrm{a}}$ & $1.57^{\mathrm{b}}$ & $1.30^{\mathrm{c}}$ & $1.39^{\mathrm{bc}}$ & $1.58^{\mathrm{b}}$ \\
& \pm 0.08 & \pm 0.06 & \pm 0.04 & \pm 0.03 & \pm 0.12 \\
\hline FER(\%) & 50.25 & 63.69 & 77.92 & 71.19 & 63.29 \\
& \pm 0.02 & \pm 0.02 & \pm 0.02 & \pm 0.06 & \pm 0.08 \\
\hline PER & $1.66^{\mathrm{c}}$ & $2.15^{\mathrm{b}}$ & $2.58^{\mathrm{a}}$ & $2.35^{\mathrm{ab}}$ & $2.11^{\mathrm{b}}$ \\
& \pm 0.07 & \pm 0.09 & \pm 0.13 & \pm 0.04 & \pm 0.17 \\
\hline APU (\%) & $26.70 \mathrm{c}$ & $31.22 \mathrm{bc}$ & $42.52 \mathrm{a}$ & $39.74 \mathrm{a}$ & $37.04 \mathrm{ab}$ \\
& \pm 1.64 & \pm 2.38 & \pm 1.96 & \pm 0.80 & \pm 1.07 \\
\hline EU (\%) & $10.27^{\mathrm{c}}$ & $12.01^{\mathrm{bc}}$ & $16.49^{\mathrm{a}}$ & $15.13^{\mathrm{a}}$ & $14.23^{\mathrm{ab}}$ \\
& \pm 0.63 & \pm 0.92 & \pm 0.71 & \pm 0.16 & \pm 1.57 \\
\hline
\end{tabular}

MeanS with different superscripts in the same row are significantly different $(P<0.05)$.

Table (5) shows the proximate chemical composition of whole fish body of Nile tilapia fed diets containing different levels of Origanum vulgare. Dry matter and crude protein content were not significantly affected by, inclusion of Origanum vulgare in fish diet. While total lipid and ash differed significantly $\mathrm{P}<0.05$ ) among diets containing Origanum vulgare. The highest content of total lipids was obtained at group fed diets contained $0.5 \%$ and 2.0 
$\%$ Origanum vulgare, while the lowest one was obtained at fish groups fed $1.5 \%$. The highest content of ash was obtained at fish groups fed diets containing $1.5 \%$ and $2 \%$, while the lowest one was obtained in fish group fed diet containing $0.5 \%$ compared with the other treatments. These results agree with those found by Abd El-Maksoud et al. (2002); Abd-Elmonem et al. (2002); Shalaby et al. (2003)and Abdelwahab et al. (2007) who found no significant differences in moisture, crude protein, of Nile tilapia fed diets containing various levels of cinnamon seed meal.

Table 5: Proximate chemical analysis on dry matter basis (mean \pm SE) of Nile tilapia fed experimental diets for 13 weeks.

\begin{tabular}{|c|c|c|c|c|c|c|}
\hline \multirow{2}{*}{ Items } & \multirow{2}{*}{ Initial } & \multirow{2}{*}{ Control } & \multicolumn{4}{|c|}{$\begin{array}{l}\text { Origanum vulgare levels in experimental } \\
\text { rations }\end{array}$} \\
\hline & & & $0.5 \%$ & $1 \%$ & $1.5 \%$ & $2.0 \%$ \\
\hline Moister\% & $\begin{array}{l}79.95^{\mathrm{a}} \\
\pm 0.39\end{array}$ & $\begin{array}{l}73.10^{\mathrm{b}} \\
\pm 0.94\end{array}$ & $\begin{array}{l}74.40^{\mathrm{b}} \\
\pm 0.75\end{array}$ & $\begin{array}{l}74.09^{b} \\
\pm 1.41\end{array}$ & $\begin{array}{l}74.78^{\mathrm{b}} \\
\pm 0.85\end{array}$ & $\begin{array}{l}75.24^{\mathrm{b}} \\
\pm 1.51\end{array}$ \\
\hline Dry matter (\%) & $\begin{array}{l}20.04^{b} \\
\pm 0.39\end{array}$ & $\begin{array}{l}26.90^{\mathrm{a}} \\
\pm 0.94\end{array}$ & $\begin{array}{l}25.60^{a} \\
\pm 0.75\end{array}$ & $\begin{array}{l}25.91^{a} \\
\pm 1.14\end{array}$ & $\begin{array}{l}25.22^{a} \\
\pm 0.85\end{array}$ & $\begin{array}{l}26.42^{\mathrm{a}} \\
\pm 0.37\end{array}$ \\
\hline 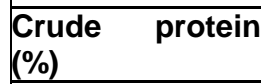 & $\begin{array}{l}58.42^{\mathrm{b}} \\
\pm 0.74 \\
\end{array}$ & $\begin{array}{l}63.85^{\mathrm{a}} \\
\pm 0.37 \\
\end{array}$ & $\begin{array}{l}62.27^{a} \\
\pm 0.90 \\
\end{array}$ & $\begin{array}{l}64.88^{a} \\
\pm 0.35 \\
\end{array}$ & $\begin{array}{l}64.43^{a} \\
\pm 1.17 \\
\end{array}$ & $\begin{array}{l}63.07^{\mathrm{a}} \\
\pm 0.74 \\
\end{array}$ \\
\hline Ether extract (\%) & $\begin{array}{l}13.11^{d} \\
\pm 0.16\end{array}$ & $\begin{array}{l}21.22^{\mathrm{bc}} \\
\pm 0.24\end{array}$ & $\begin{array}{l}24.77^{a} \\
\pm 0.70\end{array}$ & $\begin{array}{l}20.02^{\mathrm{c}} \\
\pm 0.36\end{array}$ & $\begin{array}{l}19.97^{c} \\
\pm 0.71\end{array}$ & $\begin{array}{l}21.25^{\mathrm{bc}} \\
\pm 0.74\end{array}$ \\
\hline Ash (\%) & $\begin{array}{l}28.47^{a} \\
\pm 0.83\end{array}$ & $\begin{array}{l}14.93^{\mathrm{bcd}} \\
\pm 0.17\end{array}$ & $\begin{array}{l}12.66^{d} \\
\pm 0.50\end{array}$ & $\begin{array}{l}15.1^{\text {bcd }} \\
\pm 0.06\end{array}$ & $\begin{array}{l}15.61^{b} \\
\pm 0.48\end{array}$ & $\begin{array}{c}15.68^{\mathrm{b}} \\
\pm 0.19\end{array}$ \\
\hline
\end{tabular}

Means with different superscripts in the same row are significantly different $(\mathrm{P}<0.05)$.

Table 6: Mortality rate (\%) of fingerlings Nile tilapia 0 . Niloticus fed diets containing different levels of Origanum vulgar for 90 days and challenged by $A$. hydrophila for 10 days.

\begin{tabular}{|l|c|c|c|c|c|}
\hline \multirow{2}{*}{ Items } & \multicolumn{5}{|c|}{ Origanum vulgar Levels in experimental rations } \\
\cline { 2 - 6 } & Control- $\mathbf{0 . 0}$ & $\mathbf{0 . 5} \%$ & $\mathbf{1} \%$ & $\mathbf{1 . 5} \%$ & $\mathbf{2} \%$ \\
\hline No. injected fish & 10 & 10 & 10 & 10 & 10 \\
\hline Bacteria dose (5 x 10 CFU) & $0.3 \mathrm{ml}$ & $0.3 \mathrm{ml}$ & $0.3 \mathrm{ml}$ & $0.3 \mathrm{ml}$ & $0.3 \mathrm{ml}$ \\
\hline Injection route & $\mathrm{I} / \mathrm{P}$ & $\mathrm{I} / \mathrm{P}$ & $\mathrm{I} / \mathrm{P}$ & $\mathrm{I} / \mathrm{P}$ & $\mathrm{I} / \mathrm{P}$ \\
\hline $\begin{array}{l}\text { Mortality rate (\%)after 10 } \\
\text { days of injection }\end{array}$ & 90 & 0 & 0 & 0 & 0 \\
\hline
\end{tabular}

Table 7: Economic efficiency for production of one $\mathrm{Kg}$ gain of fingerlings Nile tilapia $O$. niloticus fed diets containing different levels of Origanum vulgare

\begin{tabular}{|l|c|c|c|c|c|}
\hline \multirow{2}{*}{ Items } & \multicolumn{5}{|c|}{ Origanum vulgar Levels in experimental rations } \\
\cline { 2 - 6 } & Control- $\mathbf{0 . 0}$ & $\mathbf{0 . 5} \%$ & $\mathbf{1} \%$ & $\mathbf{1 . 5} \%$ & $\mathbf{2} \%$ \\
\hline Price/ kg feed P.T & 3.62 & 3.76 & 3.89 & 4.03 & 4.16 \\
\hline FCR ( kg feed/kg gain) & 1.99 & 1.57 & 1.30 & 1.39 & 1.58 \\
\hline Feed cost / kg gain P.T & 7.20 & 5.90 & 5.06 & 5.60 & 6.57 \\
\hline Reduction cost in kg gain & 100 & 18.06 & 29.72 & 22.23 & 8.75 \\
\hline
\end{tabular}


The results of fish challenge against $A$. hydrophila for 10 days is shown in Table (6). The mortality percentage did not observe in fish fed diet containing different levels of Origanum vulgare, while mortality percentage in fish of control group was $90 \%$. This enhanced immune response may be due to the essential oils content and extracts of origanum species containing antimicrobial, antioxidant and other biological activities (Aligiannis et al., 2001 and Milos, et al., 2000).Sahalian, 2004 tested these essential oils and extracts of Origanum species on many bacterial species (Escherichia coli, Enterobacter sp., Bacillus sp., Salmonella sp., Staphylococcus aureus, Klebsiella pneumoniae, Listeria monocytogenes and Campylobacter jejuni) and proved their antibacterial activities.

The economical evaluation of the experimental diets contained different Origanum vulgare levels $0.0,0.5 \%, 1 \%, 1.5 \%$ and $2 \%$ are shown in Table (7). The highest reduction in feed cost compared with control diet showed to produce one $\mathrm{kg}$ fish gain of treatment containing $1 \%$ Origanum vulgare. The reduction in feed cost compared with control diet showed $29.72 \%$ to produce one $\mathrm{kg}$ fish gain of treatment containing $1 \%$ Origanum vulgare levels. Previous studies showed that the use of spices in small amounts gave lower incidence cost and higher profit index of fish species (Abd-Elmonem et al., 2002; Sakr, 2003; Shalaby et al., 2003 and El-Dakar et al., 2004).

Conclusion

In a conclusion. this study,showed that using Origanum vulgare as natural feed additives in fish diet cloud improve the growth performance, feed efficiency of Nile tilapia as well as its resistant to A. hydrophila infection. Also, this study showed that the optimum level of Origanum vulgare in a practical Nile tilapia diet is $1 \%$.

\section{REFERENCES}

Abdel El-Maksoud,A. M. S.; G. E. Aboul-Fotouh; S. M.Allam and R. M. AbouZied (1999) .Efffect of marjoram leaves (Majorana hortensis L.) as a feed additive on the performance of Nile tilapia (Oreochromis niloticus) fingerlinges. Egyption J. Nutrition \& feeds. $2: 39-47$.

Abd El-Maksoud, A.M.S.; Aboul-Fotoh G.E.; Allam S.M. and Abou Zied R.M. (2002). The response of Nile tilapia to animal protein free diets supplemented with some free amino acids and some medicinal plants. Proc. $1^{\text {st }}$ Conf. Aquacult., 13-15 December.

Abdelhamid, A.M. (2008). Horses Breeding, $2^{\text {nd }}$ Ed., Monshaat Almaaref, Alexandria Deposit. no.20822 / 2002.

Abdelhamid, A.M., Khalil F.F.M, El-Barbary M.I. Zaki V.H. and Husien H.S. (2002). Feeding Nile tilapia on Biogen ${ }^{\circledR}$ to detoxify aflatoxin diets .Proc. $1^{\text {st }}$ Ann.Sc. Conf. Amin.\& Fish Prod.,Mansoura, 24 \& 25 Sep.,pp:207-230.

Abdelhamid, A.M., Mehrim A.I. and Khalil F.F. (2004).Detoxification of aflatoxin contaminated diet of tilapia fish using dietary supplementation with egg shell, Betafin $^{\circledR}$, clay or silica. J.Agric.Sci.Mansoura Univ.,29:3163-3174. 
Abdelhamid,A.M., Salem.M.F.I.and Tolan A.E.(2005). Utilization of black seed meal(Nigella sativa) in Nile tilapia (Oreochromis niloticus) diets. J. Agric. Res.Tanta Univ.,31(3):4003-419.

Abd-Elmonem A.I., Shalaby, S.M.M. and El- Dakar, A.Y. (2002). Response red tilapia to different level of some medicinal plant by-product: black seed and roquette seed meals. Proc. $1^{\text {st }}$ Sci. Conf. Aqua., El-Arish, Dec. 13-15, pp : 247-260.

Abdel-W ahab A.M.; M. M. E. Hassouna ; A. M. S. Abd El-Maksoud ; A. Abd El Tawaab; A. M. M Abu-Seef (2007).Cinnamon as a feed supplementation in Nile tilapia, (Oreochromis Niloticus), diets that redred in earthen ponds. Egyptain J. Nutrition and feeds 10 (2) Special Issue: $881-890$.

Aligiannis, N., Kalpoutzakis, E., Mitaku, S., \& Chinou, I. B. (2001): Composition and antimicrobial activity of the essential oils of two Origanum sp. Journal of Agriculture Food Chemistry, 49, 4168- 4170

AOAC (1990).Official Methods of Analysis of the Association of Official ,Analytical Chemists, $15^{\text {th }}$ ed . Association of Official Analytical Chemists, Arlington, VA.

Bamsaciuglu, H., Tokusoglu, O. and Ergul, M. (2004). The effect of oregano and rosemary essential oils or alpha-tocopheryl acetate on performance and lipid oxidation of meat enriched with n-3 PUFA's in broilers. South African of Animal Science. 34 (3). pp: 197-210.

Botsoglou, N.A., Christaki, E., Florou-paneri, P., Giannenas, I.,Papageorgiuo, G. and Spais, A.B. (2004). The effect of a mixture of herbal essential oils or a-tocopheryl acetate on performance parameters and oxidation of body lipid in broilers. South African Journal of Animal Science 34: $52-61$.

Boyd, C.E. (1990). Water Quality in Ponds for Aquaculture. Birmingham Publishing Co.Birmingham, Alabama, USA.

Chami, N., Chami, F.; Trouillas, J. and Remmal, (2004).Antifungal with carvacrol and eugenol of oral candidiasis in immunosuppressed rats. Braz.J. Infect.Dis., 8:217-226.

Craig, W.J. (1999). Health-promoting properties of common herbs American Journal of Clinical Nutrition, 70 (3)491.

Dhuley, J.N., (1999). Anti-oxidant effects of cinnamon (Cinnamomum verum) bark and greater cardamom(Amomum subulatum)seeds in rats fed high fat diet.Ind.Exp.Biol.,37:238-242.

Dorman, H.J.D. and Deans, S.G. (2000).Antimicrobial agent from plants: antimicrobial activity of plant volatile oils. J. Appl. Microbiol. 88: 308316.

Dytham, C. (1999). Choosing and Using Statistics: A Biologist's Guide. Blackwell Science Ltd., London, UK. Pp. 147.

El-Dakar, A.Y. (2004).Growth response of hybrid tilapia, Oreochromis niloticus $x$ Oreochromis auraus to diets supplemented to different levels of caraway seeds. Agric. Sci. Mansoura Univ., 29 (11): 6083- 6094. 
El-Dakar, A.Y.; Hassanien G.D.I.; Gad S.S. and Sakr S.E. (2004).Use of medical and aromatic plants in fish diets: 2 . Effect of dried basil leaves on performance of hybrid tilapia (Oreochromis niloticus x Oreochromis auraus) fingerlings. $3^{\text {rd }}$ Intern. Conf. on Anim. Production and Health in Semi-Arid Areas, Suez Canal Univ. (in press).

EL-Saidy, D. S. M. D. (1999). Effect of different levels of dry onion meal supplemented to the diets on growth, feed utilization and body composition of Nile tilapia, Oreochromis niloticus (Boulenger) fingerlings. Minufiya J. of Agric. Res. Vol. 24, 2 (1): 481492.

El-Sayed, A.-F. M. (2006).Tilapia Culture.CABI publishing,CABI International Willingford,Oxfordshire, UK.

Evans F.J., and Pharm, B.,(1975). Herbs. A Concise Guide in colour Herbs .By Fertilizer. Frantisek stary and Dr Vaclav JHirasck.lllustreated by Frantisek Severa, English Consultant F. J. Evans, B.Pharm., phosphorus.D. Hamlyn, London, New York. Sydney, Toronto.

Giannenas, I., Florou-paner, P., Papazahariadou, M., Cheristak, E.,Botsoglou, N.A. and Spais, A.B., (2003). Effect of dietary supplementation with oregano essential oil on performance of broilers after experimental infection with Eimeria tenel. Journal British Poultry Science. 57 (2):99-106.

Goering, H.K. and P.G. Van Soest (1970). Forage fiber analysis (apparatus, reagent, procedures, and some applications). US Dept. Agric. Handbook, Washington D.C., USA, p.

Hanafy, M.M. (1995). The use of anise, fennel and ginger as a feed additive in the nutrition of broilers, M. Sc. Thesis, Fac. Agric., Alex. Univ.

Ibrahim, M.; S.A. Abd El-Latif and A.T. EL-Yamany (1998). Effects of some natural growth promoters to broiler chickens diets on growth plants grown wild in Greece. Z. Lebensm. Uters. Forsch., 97: 20-23.

Jamroz, D.; Werlecki, T.J.; Wiliczklewicz, A. and Skorupinska, J. (2003). Influence of phtogeneic extracts on gut microbial status in chickens. In: Proc. $14^{\text {th }}$

Jantan, I.B.;Yassin, M.S.M., Chin, C.B; Chn, L.L. and Sim, N.L. (2003). Antifungal activity of the essential oils nine zingiberaceae species. Journal British Poultry Science. 41 (5): 392-397.

Milos, M., Mastelic, J. and Jerkovic, I. (2000). Chemical composition and antioxidant effect of glycosidically bound volatile compounds from oregano (Origanum vulgare L. ssp. hirtum. Food Chemistry, 71, 79-83.

Mitsch, P., Zitterl-eglseer, K., Kohler, B., Gabler, C., Losa, R. and Zimpernik, I. (2004). The effect of two different blends of essential oil components on the Proliferation of clostridium Perfringens in the Intestines of broiler chickens. 2004 Poultry Science 83:669-675.

Montasir A.H. and Hassib, M. (1956). Manual flora of Egypt, Impreimerie Masr. S.A.E.

Nevas, M.; Korhonen, A.R.; Lindstrom, M.; Turkki, P. and Korkela, H. ( 2004). Antibacterial efficiency of Finnish spices essential oils against pathogenic and spoilage bacteria .J.Food protect., 67:199-202. 
Seden, M. E. A. et al.

NRC (National Research Council) (1993). Nutrient requirements of fish. Committee on Animal Nutrition. Board on Agriculture. National Research Council. National Academy Press. Washington DC, USA.

N.R.C. (1994). Nutrient requirements of poultry $9^{\text {th }}$ Rev. Ed. National Academy press, Washington, D.C., USA

Sahalian, M.D.(2004). Diosgenin, asteroid saponins of Trigonella foenum graecum (fenugreek), inhibits azoxymethane- induced aberrant crypt foic formation in F344 rats and induces apoptosis in HT-29 human colon cancer cells. Cancer Epidermiol biomarkers Prev.2004Aug;13 (8):1392-8.

Sakr, S. E. (2003). Studies on the feeding attractants for fish. M.Sc Thesis. Fac. Environ. Agric. Sci., El-Arish, Suez Canal Univ., Egypt. 83:669675.

Schäperclaus, W.; Kulow, H. and Schreckenback, K. (1992). Fish Disease Vol.I A.A. Balkema / Rotterdam.

Shalaby, S. M. M. (2004). Response of Nile tilapia, Oreochromis niloticus fingerlings to diets supplemented with different levels of fenugreek seeds (Hulba). J. Agric. Mansoura Univ., 29: 2231-2242.

Shalaby,S.M.M.; Abd-Elmonem A.I.and El- Dakar, A.Y. (2003).Enhancement of growth performance .feed and nutrient utilization, of Nile tilapia, Oreochromis niloticus, using of licorice roots(Erksous) as a feed attractive.J. Egypt. Acad Soc.Environ.Develop. (B-Aquaculture), 4 (2):119-142.

Tollba, A.A.H. (2003). Using some natural additives to improve physiological and productive performance of broilers chicks under high temperature conditions1-Theme (thyme Vulgaris L.) or fennel (Foeniculum vulgare L.) Egypt. Poult. Sci., 23 (11): $313-326$.

Wang, S. Y.; Chen, P .F and Chang, S.T. (2005). Antifungal activities of assential oils and their constituents from indigenous cinnamon (Cinnamomum osmophloeum) leaves against wood decay fungi. Bioresour. Technol, $96: 813-818$.

Zheng, W. and Wang, S. Y. (2001).antioxidant activity and phenolic compounds in selected .J.Agric Food Chem.49:5165-5170. 


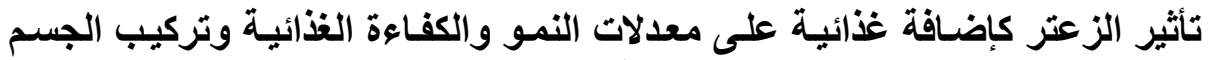

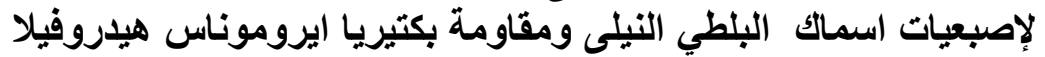

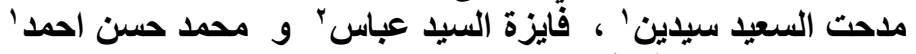

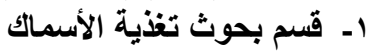
r ـ قسم بحوث إنتاج الأسماك ونظم الاست الاستزراع السمكي المعمل المركزي لبحوث الثروة السمكية. العباسة ـأبو حماد ـشرقية الأنية

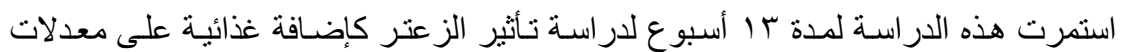

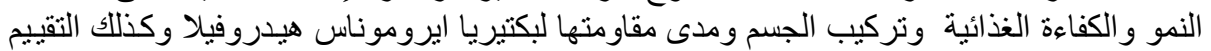

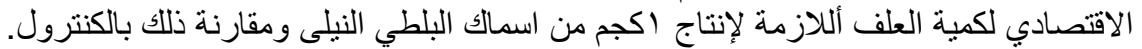

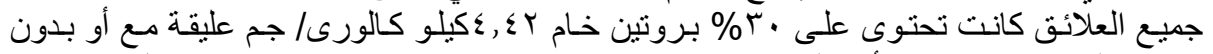

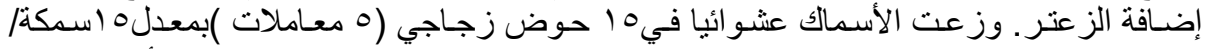

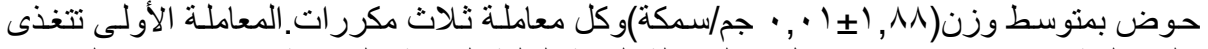

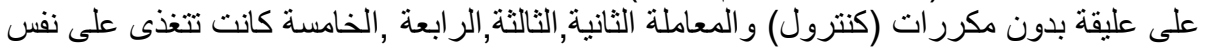

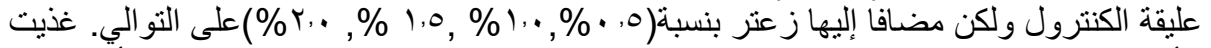

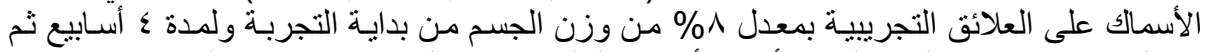

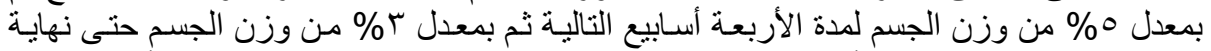

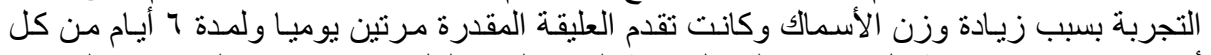

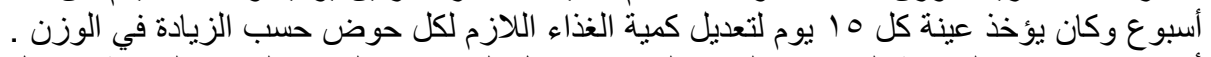

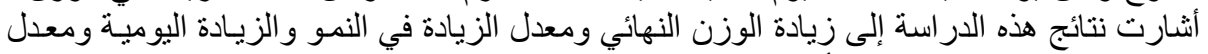

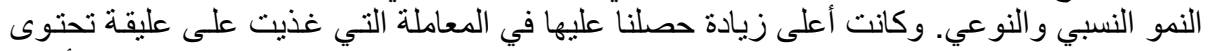

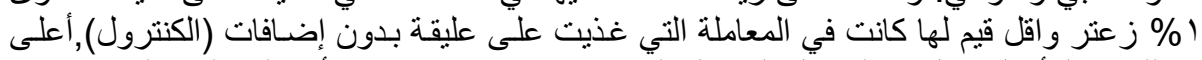

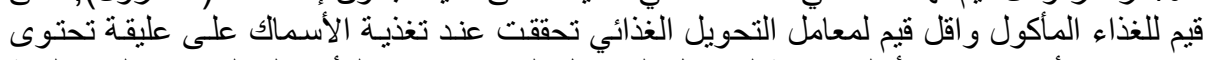

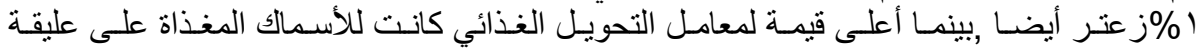

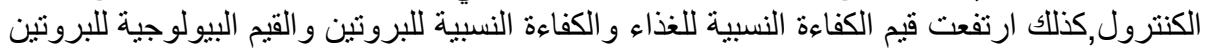

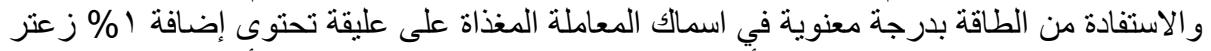

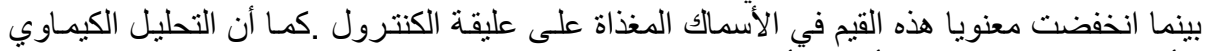

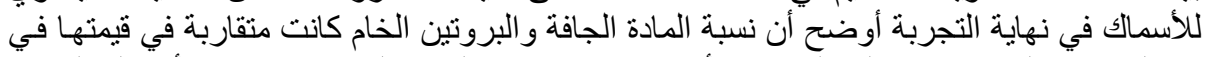

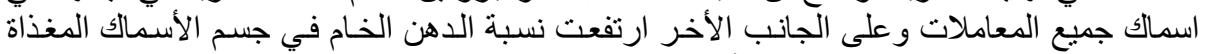

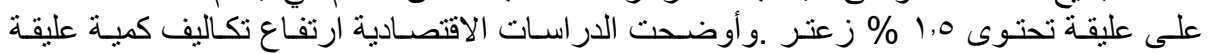

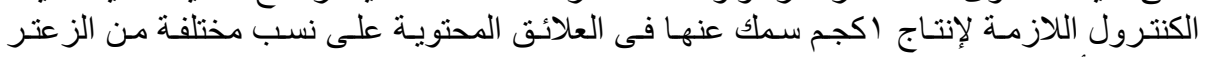

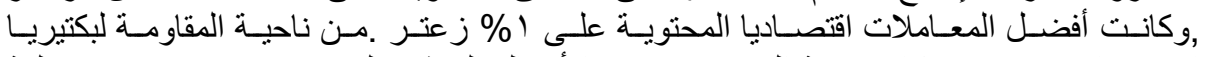

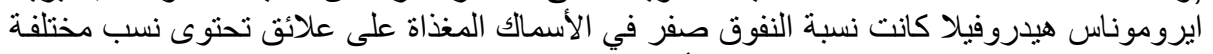

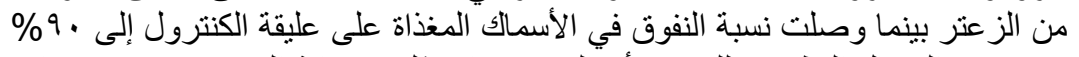

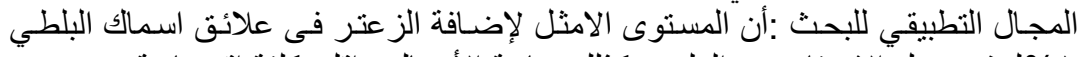

النيلى هي \\% لرفع معدل الاستفادة من العلف وكذلك مناعة الأسماك و اقل تكلفة القتصادية. 